\title{
THE INFLUENCE OF SERVICE QUALITY AND STORE ATMOSPHERE ON CUSTOMER SATISFACTION
}

\author{
Miswanto $^{1 *}$, Yessi Ria Angelia ${ }^{2}$ \\ ${ }^{1,2}$ YKPN School of Business (STIE YKPN), Yogyakarta, Indonesia \\ *Corresponding author; Email: miswanto.ykpn@gmail.com
}

\begin{abstract}
This research examines the influence of service quality (tangibles, reliability, responsiveness, assurance, and empathy) and store atmosphere on customer satisfaction and the influence of customer satisfaction on repurchase intention, trust, and word of mouth on customers of souvenir stores in Yogyakarta. Selection of the sample is done by using purposive sampling with one criterion: they have shopped in souvenir stores in Yogyakarta. Data are collected by using questionnaires and 200 souvenir store customers participate in this study. The data are analyzed by using Structural Equation Modeling (SEM) with Amos computer program. The findings show that none of service quality's dimension: tangibles and store atmosphere have positive influences on customer satisfaction.
\end{abstract}

Keywords: Service quality, dimensions of service quality, customer satisfaction, store atmosphere.

\section{Introduction}

Tourism is one of the leading sectors in Yogyakarta. This is supported by its high potential tourism opportunities as well as the supporting infrastructure of adequate tourism such as accommodation, transportation, restaurants, telecommunications, entertainment, and souvenir shops. Various businesses evolve due to the increasing of tourists visiting Yogyakarta. Snacks and culinary industry are businesses that are quite attractive for both young and old generations. It is not the only manufacturers which develop, but souvenir shops also increase. They compete in determining the strategies for customers to come to the stores. The competition is more competitive, companies must have a good marketing strategy for the product produced.

Long term customer satisfaction is the goal of the companies so they can survive (Hadiati \& Ruci, 1999). Related to customer satisfaction, service quality can affect customer satisfaction. The quality of service establishes a strong relationship between the customers and the companies (Sriwidodo \& Indriastuti, 2010). The organization can be successful in providing service when the services meet the expectations of customerss (Hossain \& Islam, 2012).

Parasuraman, Zeithaml and Berry (1988) share Service Quality (SERVQUAL) and defined it into five dimensions: tangibles, reliability, responsiveness, assurance, and empathy. Another thing that can affect customers when visiting souvenir shops is the shop atmosphere. Store atmosphere is the atmosphere created to provide added value and give a positive impresssion in the minds of costumers (Tunjungsari,
Fauzi, \& Mawardi, 2016). Reality shows that there are some employees at souvenir shops in Yogyakarta who have less attention to the customers. Sometimes employees are busy doing their jobs, so they forget that customers' needs should be considered. Sometimes employees are busy talking with fellow employees. The quality of the services provided by some souvenir shops is less than the maximum. But there are some souvenir shops which are still concerned about the quality of service. There are still many souvenir shops that provide the employees who are friendly to the customers.

Customer satisfaction is the priority for the growth of any organization (Hamza, 2009). Satisfaction arises from perceptions and expectations (Sabir, Ghafoor, Hafezz, Akhtar, \& Rehman 2014). Customer satisfaction will be fulfilled when what is given by the company in accordance with what is perceived by the customers (Sriwidodo \& Indriastuti, 2010). Continuous customer satisfaction is the goal of the company so the company can survive (Hadiati \& Ruci, 1999). Putro, Semuel, Karina and Brahmana (2014) define customer satisfaction as feelings or emotional assessment of customers against the use of products and services in which the expectations of customers are met. Customer satisfaction is the main source of income and a major key to win the market (Xia, Jie, Chaolin, \& Feng 2009). All business and marketing activities are certainly aiming at customer satisfaction (Saeed, Niazi, Arif, \& Jehan 2011).

Quality of service is a factor that affects the success of the organization. Success can be achieved by providing qualified quality services (Siddiqi, 2011). Organizations focus on and give special 
attention to the quality of service. Because customers do not just want a high quality product, but they also want the high quality products and services (Puni, Okoe, \& Damnyag, 2014). The success of the organization in providing service can occur when the services provided meet the expectations of customers (Hossain \& Islam, 2012). Parasuraman et al. (1988) share the Service Quality (SERVQUAL) and defined it into five dimensions: tangibles, reliability, responsiveness, assurance, and empathy. The physical evidence is also important e.g. physical facilities, equipment, and performance of employees. Reliability is related to the ability to show the promised service and accurately from the first. Responsiveness is the willingness of employees to assist customers and provide services quickly. The next dimension is assurance or guarantee. It is the knowledge and courtesy of employyees and their ability to increase trust and customers' confidence. The last dimension is empathy. It is the attention given by the company to its customers.

According to Tunjungsari et al. (2016) store atmosphere is the atmosphere created or generated to provide the added value and give a positive impression in the minds of customers. The atmosphere of the store is also known as the psychological atmosphere of the store. Meanwhile, according to Hussain and Ali (2015) the atmosphere of the shop is one of the things that customers consider when going to the shop. The pleasant atmosphere will affect the level of customer satisfaction (Sukma, Fauzi, \& Yaningwati, 2012). Kusumowidagdo (2010) states that the conditions in the shop can influence customer behavior.

Sriwidodo and Indriastuti (2010) define quality of service as a very important factor in increasing sales, especially in attracting new customers, maintaining existing customers, and avoiding the customer buying the products in other companies. Success can be achieved by providing good quality services. The quality services can drive customer satisfaction (Siddiqi, 2011). Based on the dimensions of service quality, the first hypothesis would be divided as follows:

$H_{l a}$ : Tangibles as a dimension of quality service has a positive effect on customer satisfaction.

Reliability is a second dimension of service quality which can also affect customer satisfaction. If the company can provide the services which are promised, it will lead to customer satisfaction. Thus, the hypothesis is formulated:

$H_{l b}$ : Reliability as a dimension of quality services has a positive effect on customer satisfaction.

The third dimension of the quality service is responsiveness. It is the willingness of employees to assist customers and provide fast service or responsiveness. The faster employees respond questions or customer demand, the level of customer satisfaction will be higher. Thus, the hypothesis is formulated:

$H_{l c}$ : Responsiveness as a dimension of quality service has a positive effect on customer satisfaction.

Assurance deals with the courtesy of employees and their ability to increase customers' confidence. With the guarantee of treatment of employees, customers will be more satisfied. Thus, the hypothesis is formulated:

$H_{l d}$ : Assurance as a dimension of quality service has a positive effect on customer satisfaction.

Empathy is a form of attention from corporate customers. The more the employees give attention, customers will be more satisfied. Thus, the hypothesis formulated is:

$H_{l e}$ : Empathy as a dimension of quality service has a positive effect on customer satisfaction.

According Tunjungsari et al. (2016) atmosphere of the shop (store atmosphere) is the atmosphere created or generated to provide added value and give a positive impression in the minds of customers. Meanwhile, according to Hussain and Ali (2015) the atmosphere of the shop is one of the things that customers consider when going to shop. The pleasant atmosphere will affect the level of customer satisfaction.

$H_{2}$ : Store atmosphere has a positive effect on customer satisfaction.

Customers who are satisfied with a product or company will be loyal and can increase customers' confidence in the product (Majid et al., 2011). With confidence, the customers have reached satisfaction at the highest level (Habib \& Aslam, 2014). The more satisfied with what is given by the company, the confidence of customers to the company will be increasing.

\section{Research Method}

The data used in this study are primary data. The sampling method is done by using purposive sampling method. This method of selecting samples with specific criteria. The criterion used in the study respondents are people who have shopped at the souvenir shops in Yogyakarta.

The validity test is the first test in this study. Validity testing is performed by using SPSS 22 . The 
question of validity of items is done by using factor analysis. The item of questionnaire will be valid if it reaches the loading factor of more than 0.5 . The second test is the test of reliability. Cronbach's alpha score is commonly used with the criterion of larger than 0.6. The greater the Cronbach's alpha score is the better research instrument. The third testing is hypotheses testing using Structural Equation Modeling (SEM) using Analysis Moment Structure (AMOS).

\section{Result and Discussion}

The amount of 200 questionnaires are distributed and all of them can be used. Respondents who participated in this study consist of the male respondents 98 people (49\%) and 102 female respondents $(51 \%)$. The majority of respondents' ages are 21-26 years old $(51.5 \%)$. The majority of respondents with undergraduate educational background is 87 respondents $(43.5 \%)$. The majority of respondents who are students are 88 people (44\%). From income range, the majority of respondents have revenues of $<1$ million per month. As shown on Table 1-7, all items of the questionnaire are valid because the loading factors are more than 0.5. And Table 8 shows that the reserach instruments are reliable.

Table 1

Validity Test Result of Variable Quality of ServiceTangibles Dimension

\begin{tabular}{llcl}
\hline Code & \multicolumn{1}{c}{ Statements } & $\begin{array}{c}\text { Loading } \\
\text { Factor }\end{array}$ & Status \\
\hline TAN $_{1}$ & $\begin{array}{l}\text { The location souvenir shop } \\
\text { that I visit is easy to get. }\end{array}$ & 0.780 & Valid \\
$\mathrm{TAN}_{2}$ & $\begin{array}{l}\text { The layout of souvenir shop } \\
\text { that I visit allows me to choose } \\
\text { the products easily. }\end{array}$ & 0.778 & Valid \\
$\mathrm{TAN}_{3} \begin{array}{l}\text { The parking area of souvenir } \\
\text { shops that I visit is large. }\end{array}$ & 0.697 & Valid \\
$\mathrm{TAN}_{4} \begin{array}{l}\text { The souvenir shop that I visit } \\
\text { always maintain the } \\
\text { cleanliness of the store. }\end{array}$ & 0.653 & Valid \\
\hline
\end{tabular}

Table 2

Validity Test Result of Variable Quality of ServiceReliability Dimension

\begin{tabular}{clcc}
\hline Code & \multicolumn{1}{c}{ Statements } & $\begin{array}{c}\text { Loading } \\
\text { Factor }\end{array}$ & Status \\
\hline REL $_{1}$ & $\begin{array}{l}\text { The souvenir shop that I visit } \\
\text { provides a complete product. }\end{array}$ & 0.632 & Valid \\
REL $_{2}$ & $\begin{array}{l}\text { I am not disappointed } \\
\text { shopping at a souvenir shop } \\
\text { that I visit. }\end{array}$ & 0.825 & Valid \\
REL $_{3}$ & $\begin{array}{l}\text { Products sold in souvenir } \\
\text { shops that I visited are varied. } \\
\text { REL }\end{array}$ & 0.804 & Valid \\
& $\begin{array}{l}\text { The souvenir shop that I visit } \\
\text { sell good quality products. }\end{array}$ & 0.737 & Valid \\
\hline
\end{tabular}

Table 3

Validity Test Result of Variable Quality of ServiceResponsiveness Dimension

\begin{tabular}{llcc}
\hline Code & \multicolumn{1}{c}{ Statements } & $\begin{array}{c}\text { Loading } \\
\text { Factor }\end{array}$ & Status \\
\hline RES1 & $\begin{array}{l}\text { The employees of souvenir } \\
\text { shops that I visit are responsive } \\
\text { to answer customers } \\
\text { questions. }\end{array}$ & 0.744 & Valid \\
RES2 & $\begin{array}{l}\text { The employees of souvenir } \\
\text { shop that I visit are responsive } \\
\text { to serve customers. }\end{array}$ & 0.812 & Valid \\
RES3 & $\begin{array}{l}\text { The employees of souvenir } \\
\text { shop that I visit are responsive } \\
\text { to give customers' demands }\end{array}$ & 0.822 & Valid \\
RES4 & $\begin{array}{l}\text { The employees of souvenir } \\
\text { shop that I visit are willing to } \\
\text { help customers immediately. }\end{array}$ & 0.792 & Valid \\
\hline
\end{tabular}

Table 4

Validity Test Result of Variable Quality of Service Assurance Dimension

\begin{tabular}{clcc}
\hline Code & \multicolumn{1}{c}{ Statements } & $\begin{array}{c}\text { Loading } \\
\text { Factor }\end{array}$ & Status \\
\hline ASR1 & $\begin{array}{l}\text { I feel that shopping at a } \\
\text { souvenir shop that I visited is } \\
\text { the right choice. }\end{array}$ & 0.799 & Valid \\
ASR2 & $\begin{array}{l}\text { The souvenir shop I visited } \\
\text { provides good quality service. } \\
\text { The souvenir shop that I visit }\end{array}$ & 0.845 & Valid \\
provides a lot of employees to \\
$\begin{array}{l}\text { help customerss. } \\
\text { ASR4 }\end{array}$ & $\begin{array}{l}\text { Employees of the souvenir } \\
\text { shop that I visit are polite. }\end{array}$ & 0.644 & Valid \\
\hline
\end{tabular}

Table 5

Validity Test Result of Variable Quality of Service Empathy Dimension

\begin{tabular}{|c|c|c|}
\hline Statements & $\begin{array}{l}\text { Loading } \\
\text { Factor }\end{array}$ & Status \\
\hline $\begin{array}{l}\text { EMP1 Employees of the souvenir } \\
\text { shop that I visit are willing } \\
\text { to help customers properly. }\end{array}$ & 0.751 & Valid \\
\hline $\begin{array}{l}\text { EMP2 Employees of the souvenir } \\
\text { shop that I visited shows } \\
\text { concern by offering assistance } \\
\text { to customers. }\end{array}$ & 0.791 & Valid \\
\hline $\begin{array}{l}\text { EMP3 Employees of the souvenir } \\
\text { shop that I visit are friendly in } \\
\text { serving customers. }\end{array}$ & 0.834 & Valid \\
\hline $\begin{array}{l}\text { EMP4 Employees of the souvenir } \\
\text { shop that I visited pay attention } \\
\text { to the customers. }\end{array}$ & 0.784 & Valid \\
\hline
\end{tabular}


Table 6

Validity Test Result of Stores Atmosphere Variable

\begin{tabular}{llcc}
\hline Code & \multicolumn{1}{c}{ Statements } & $\begin{array}{c}\text { Loading } \\
\text { Factor }\end{array}$ & Status \\
\hline STO1 & $\begin{array}{l}\text { Temperatures in the souvenir } \\
\text { shop that I visited made me } \\
\text { feel comfortable. }\end{array}$ & 0.648 & Valid \\
STO2 & $\begin{array}{l}\text { The souvenir shop I visited } \\
\text { was not stuffy. }\end{array}$ & 0.829 & Valid \\
STO3 & $\begin{array}{l}\text { The souvenir shop that I } \\
\text { visited had lighting that } \\
\text { supports me in shopping. }\end{array}$ & 0.771 & Valid \\
STO4 $\begin{array}{l}\text { The souvenir shop that I } \\
\text { visited had a peaceful } \\
\text { atmosphere. }\end{array}$ & 0.596 & Valid \\
\hline
\end{tabular}

Table 7

Validity Test Result of Customers Satisfaction Variable

\begin{tabular}{cccc}
\hline Code & \multicolumn{1}{c}{ Statements } & $\begin{array}{c}\text { Loading } \\
\text { Factor }\end{array}$ & Status \\
\hline KKN1 & $\begin{array}{l}\text { I am satisfied with the products } \\
\text { and services that I get }\end{array}$ & 0.776 & Valid \\
KKN2 $\begin{array}{l}\text { I am satisfied with the } \\
\text { response of the employees } \\
\text { when I get a difficulty }\end{array}$ & 0.833 & Valid \\
KKN3 $\begin{array}{l}\text { My experience of shopping in } \\
\text { the souvenir shop that I visited } \\
\text { makes me happy }\end{array}$ & 0.817 & Valid \\
KKN4 $\begin{array}{l}\text { I am satisfied with the } \\
\text { experience of shopping in the } \\
\text { souvenir shop that I visited. }\end{array}$ & 0.817 & Valid \\
\end{tabular}

Table 8

Reliability Test Results

\begin{tabular}{lcc}
\hline Variable & Cronbach's Alpha & Category \\
\hline Tangibles & 0.694 & Reliable \\
Reliability & 0.733 & Reliable \\
Responsiveness & 0.803 & Reliable \\
Assurance & 0.662 & Reliable \\
Empathy & 0.796 & Reliable \\
Store Atmosphere & 0.666 & Reliable \\
Customers Satisfaction & 0.827 & Reliable \\
\hline
\end{tabular}

Descriptive statistical analysis used in this study is taken from the average response of all respondents in each of the indicators with the range of scores 1-5. All variables have a score of more than 3 , so they indicate that on average respondents considered the same thing. Fit model testing is done by looking at three types of values, and the results are as follows. The score of GFI (goodness of fit index) is 0.847 . It is good enough because it is near 0.9. It shows that there is a match between the model and the data. The score of RMR (root mean square) is 0.024 which meets the criterion. The score of RMSEA (root mean square error of estimation) is 0.161 . It does not meet the criterion. The scores of incremental fit shows that those are not really good.
Table 9

Hypothesis Test Results

\begin{tabular}{|c|c|c|c|c|}
\hline & Hypothesis & $\begin{array}{c}\text { Standardized } \\
\text { Regression } \\
\text { Weights }\end{array}$ & $\begin{array}{c}\text { Proba- } \\
\text { bility }\end{array}$ & Status \\
\hline$\overline{H_{l a}:}$ & $\begin{array}{l}\text { Tangibles as a } \\
\text { dimension of } \\
\text { quality service } \\
\text { has a positive } \\
\text { effect on } \\
\text { customer } \\
\text { satisfaction }\end{array}$ & 0.126 & $P<0.1$ & $\begin{array}{l}\text { Hypothesis } \\
\text { is supported }\end{array}$ \\
\hline$H_{l b}:$ & $\begin{array}{l}\text { Reliability as a } \\
\text { dimension of } \\
\text { quality services } \\
\text { has a positive } \\
\text { effect on custo- } \\
\text { mer satisfaction. }\end{array}$ & 0.123 & 0.399 & $\begin{array}{l}\text { Hypothesis } \\
\text { is not } \\
\text { supported }\end{array}$ \\
\hline$H_{l c}:$ & $\begin{array}{l}\text { Responsiveness } \\
\text { as a dimension } \\
\text { of quality service } \\
\text { has a positive } \\
\text { effect on } \\
\text { customer } \\
\text { satisfaction. }\end{array}$ & -0.031 & 0.847 & $\begin{array}{l}\text { Hypothesis } \\
\text { is not } \\
\text { supported }\end{array}$ \\
\hline$H_{l d:}$ & $\begin{array}{l}\text { Assurance as a } \\
\text { dimension of } \\
\text { quality service } \\
\text { has a positive } \\
\text { effect on } \\
\text { customer } \\
\text { satisfaction. }\end{array}$ & 0.266 & 0.254 & $\begin{array}{l}\text { Hypothesis } \\
\text { is not } \\
\text { supported }\end{array}$ \\
\hline$H_{l e}:$ & $\begin{array}{l}\text { Empathy as a } \\
\text { dimension of } \\
\text { quality service } \\
\text { has a positive } \\
\text { effect on } \\
\text { customer } \\
\text { satisfaction. }\end{array}$ & 0.326 & 0.117 & $\begin{array}{l}\text { Hypothesis } \\
\text { is not } \\
\text { supported }\end{array}$ \\
\hline $\mathrm{H}_{2}$ : & $\begin{array}{l}\text { Store atmosphere } \\
\text { has a positive } \\
\text { effect on } \\
\text { customer } \\
\text { satisfaction. }\end{array}$ & 0.360 & $P<0.1$ & $\begin{array}{l}\text { Hypothesis } \\
\text { is } \\
\text { supported }\end{array}$ \\
\hline
\end{tabular}

As shown on Table 9, service in the form of physical evidence (tangible) affects customer satisfaction. Tangibles can be a large parking area, a clean place. This study suggests that tangibles positive significant effect on customer satisfaction $(\beta=0.126$; $p<0.1$ ). This is supported by a research of Masruri (2013) which states that tangibles positively affect customer satisfaction. Thus the respondents perceive physical evidence (tangibles) to affect their satisfaction. Physical evidence is considered important by customers. The cleanliness of the store, a large parking area, and the ease of customers are considered. 
Reliability is the ability to show the promised service reliably and accurately. The services provided reliability and accurately can affect customer satisfaction. But in this study, it shows that reliability does not significantly influence customers satisfaction $(\beta=$ $0.123 ; p>0.1)$. This is supported by a research conducted by Kitapci, Akdogan, and Dortyol (2014) which show that reliability does not significantly influence customer satisfaction. Reliability as one of the dimensions of service quality is not proven to positively affect customer satisfaction. Whether or not the high reliability of the service provided does not affect the perceived customer satisfaction. This is because usually most of the souvenir shops are selfservice. Customers of souvenir shops are free to choose products. This can usually be done without the help of employees. So the reliability of the employees does not affect customer satisfaction.

Responsiveness is the willingness of employees to help customers quickly. Employees who can provide service quickly affect customer satisfaction. But this study suggests that the responsiveness has no significant effect on customer satisfaction $(\beta=-0.031$; $p>0.1$ ). This indicates that the responsiveness has no significant effect on customer satisfaction. Customers assume responsiveness does not really matter, because the gift shops are usually self-service. Customers choose the products by themselves. The customers rarely need help from employees.

Customer services in the form of a guarantee (assurance) is to increase confidence and customer confidence affect customer satisfaction. But this study suggests that the assurance has no significant effect on customer satisfaction $(\beta=0.266 ; p>0.1)$. This is supported by a research conducted by Kitapci, Akdogan, and Dortyol (2014) which shows that the assurance has no significant effect on customer satisfaction. Assurance is considered less important, because most of the souvenir shops in Yogyakarta let customers choose their own desired products on the shelf that has been provided. It is considered less important to customers.

Service in the form of attention (empathy) can affect customer satisfaction. Empathy may be the help provided by the employees. But this study suggests that empathy does not have a significant effect on customer satisfaction $(\beta=0.326 ; p>0.1)$. This is in line with a research showing that empathy does not significantly influence customer satisfaction. The same as the other dimensions of service quality, empathy tend not to affect customer satisfaction for most of the souvenir shops.

A pleasant atmosphere can affect customer satisfaction. There is an evidence in this study that shows that the atmosphere of the shops has significant effect on customer satisfaction. Pleasant atmosphere store can encourage their customer satisfaction $(\beta=$ $0.360 ; p<0.1)$. This result is supported by a research of Kusumowidagdo (2010) which states that the conditions in the shop can affect customer satisfaction.

\section{Conclusions and Implications}

This study contributes to the literature on the relationship of the dimensions of service quality and store atmosphere to customer satisfaction and the relationship of trust, word of mouth, and repurchase intention at a store or company that sells local products. In this study only tangibles have positive effect on custumer satisfaction. The other four dimensions of service quality are not proven.

As most of souvenir shops in Yogyakarta are self service shops, tangibles become very important in the minds of customers. Customers pay more attention on the locations of the shops, like their easy access, large parking area, cleanliness of shops, shelf layout that allow customers to choose the souvenirs by themselves, the room temperature, lighting support an the like. These tangibles can make customers feel comfortable when shopping,

The result is also useful for the practitioner group, the owners of souvenir shops in understanding how to satisfy customers. The next strategy business of the owners of souvenir shops is to create an atmosphere that is more convenient. The more comfortable the atmosphere of the stores, the more satisfied the customers are. So, when the customer satisfaction is created, it would be beneficial for the business.

\section{References}

Habib, S. \& Aslam, S. (2014). Influence of brand loyalty on customers repurchase intentions of Coca-Cola. European Journal of Business and Management, 6(14), 168-174.

Hadiati, S. \& Ruci, S. (1999). Analisis kinerja kualitas pelayanan terhadap kepuasan pelanggan pada Telkomsel Malang Area. Jurnal Manajemen dan Kewirausahaan, 1(1), 56-64.

Hamza, V. K. (2013). A Study on the mediation role of customer satisfaction on customer impulse and involvement to word of mouth and repurchase intention. IJBIT, 7(1), 62-66.

Hossain, M. J. \& Islam, M. A. (2012). Understanding perceived service quality and satisfaction. Performance Measurement and Metrics Journal, 13(3), 169-182. 
Hussain, R. \& Ali, M. (2015). Effect of store atmosphere on customers purchase intention. International Journal of Marketing Studies, 7(2), 3543.

Kitapci, O., Akdogan, C., \& Dortyol, I. T. (2014). The impact of service quality dimensions on patient satisfaction, repurchase intentions and word-of-mouth communication in the public healthcare industry. Procedia-Social and Behavioral Sciences 148, 161-169.

Kusumowidagdo, A. (2010). Pengaruh desain atmosfer toko terhadap perilaku belanja (studi atas pengaruh gender terhadap respon pengunjung toko). Integritas - Jurnal Manajemen Bisnis, 3(1), 17-32.

Majid, S., Foo, S., Luyt, B., Zhang, X., Theng, Y.L., Chang, Y., \& Mokhtar, I. A. (2011). Adopting evidence based practice in clinical decision making: nurses' perceptions, knowledge, and barriers. Journal of the Medical Library Association, 99(3), 229-236.

Masruri, A. (2013). Kualitas layanan terhadap kepuasan pelanggan PT. Tiki Jalur Nugraga Ekakurir (JNE) Surabaya. Jurnal Ilmu \& Riset Manajemen, 2(7), 1-22.

Parasuraman, A., Zeithaml, V. A., \& Berry, L. L. (1988). SERVQUAL: A multiple-item scale for measuring customer perceptions of service quality. Journal of Retailing, 64(1), 12-40.

Puni, A., Okoe, A., \& Damnyag, J. B. (2014). A gap analysis of customer perceptions and expectation of service quality amongst mobile telephony companies in Ghana. Journal of Management and Strategy, 5(3), 60-70.

Putro, S.W., Semuel, H., Karina, R., \& Brahmana. (2014). Pengaruh kualitas layanan dan kualitas produk terhadap kepuasan pelanggan dan loyalitas konsumen restoran Happy Garden Surabaya. Jurnal Manajemen Pemasaran, 2(1), 1-9.
Sabir, R. I., Ghafoor, O., Hafezz, I., Akhtar, N., \& Rehman, A. U. (2014). Factors affecting customers satisfaction restaurant industry in Pakistan. International Review of Management and Business Research, 3(2), 869-876.

Saeed, I., Niazi, M. A., Arif, M., \& Jehan, N. (2011). Antecedents of customer satisfaction and its outcomes (a study of Pakistan service sector). Interdisciplinary Journal of Contemporary Research in Business, 3(8), 877-889.

Siddiqi, K. O. (2011). Interrelations between service quality attributes, customer satisfaction and customer loyalty in the retail banking sector in Bangladesh. International Journal of Business and Management, 6(3), 12-36.

Sriwidodo, U. \& Indriastuti R. T. (2010). Pengaruh dimensi kualitas pelayanan jasa terhadap kepuasan nasabah. Jurnal Ekonomi dan Kewirausahaan, 10(2), 164-173.

Sukma, E. A., Fauzi, A., \& Yaningwati, F. (2012). Suasana toko dalam menciptakan emosi dan pengaruhnya terhadap keputusan pembelian (survey pada pengunjung retail Hypermart Malang Town Square Kota Malang). Jurnal Profit, 6(1), 60-87.

Tunjungsari, S. V., Fauzi, A., \& Mawardi, M. K. (2016). Pengaruh store atmosphere (suasana toko) terhadap emosi serta dampaknya pada keputusan pembelian (survei pada pembeli di Ria Djenaka Cafe dan Resto, Kota Batu). Jurnal Administrasi Bisnis (JAB), 30(1), 1-7.

Xia, W., Jie, Z., Chaolin, G., \& Feng, Z. (2009). Examining antecedents and consequences of tourist satisfaction: a structural modeling approach. Tsinghua Science and Technology, 14(3) 397-406. 